MARKETING AND BRANDING
RESEARCH $\begin{gathered}\text { INDUSTRIAL } \\ \text { MANAGEMENT } \\ \text { INSTITUTE }\end{gathered}$

\title{
The Impact of the Service Innovativeness on Perceived Overall Service Quality, Customer Loyalty and Perceived Customer Value in Shopping Sites
}

\author{
Emine Senbabaoglu
}

Gazi University, Ankara, Turkey

\begin{abstract}
Keywords:

Website Service

Innovativeness, Perceived

Overall Service Quality,

Customer Loyalty,

Perceived Customer

Value

Correspondence:

eminesenbabaoglu@gmail. com

Associated with the change of life style, due to reasons such as time constraints, information access, and alternatives comparison easiness, consumers prefer directed shopping on the internet. Shopping is done along with the initiation by the internet, in the scope of study such as web site service innovativeness, perceived overall service quality, customer loyalty, and perceived customer value. What are the effects of service innovativeness on perceived overall service quality, customer loyalty and perceived customer value? In order to answer this question, theoretical and empirical research is structured. From a holistic point of view the results suggest the positive effect of service innovativeness on perceived overall service quality, customer loyalty, and perceived customer value. Website service innovativeness influences behavioural intentions such as perceived overall service quality, customer loyalty, and perceived customer value. Following the examination of the results, the present article discussed the implications for practice and future research.
\end{abstract}

CAIMI Journals

\section{Introduction}

There has been a remarkable growth in business to consumer electronic commerce since the commercialization of the Internet in early 1990s (Ranganathan \& Ganapathy, 2002). Purchasing activities on the internet have an important effect on the purchasing behavior of the customers due to changes in the internet technology.

Yoo \& Donthu (2001) defined shopping sites used on the Internet as places where consumers can spend time, evaluate goods and services, place orders, and buy goods or services. Shopping from shopping sites is classified as a service. Recently, as the service- 
based economy has become dominant, the service delivery process is also becoming important (McDonald, De Chernatony, \& Harris, 2001). In this sense, in services, innovation is essential to the survival of firms, especially in competitive environments (Agarwal, Erramili, \& Dev, 2003).

There are limited study about service innovativeness in the literature (Carmona-Lavado, Cuevas-Rodríguez, \& Cabello-Medina, 2013; Lee, Ginn, Naylor, 2009; Liu, 2013; Zolfagharian \& Paswan, 2009). Website innovativeness is a new concept to marketing discipline. There is only one study about website service innovativeness (O'Cass \& Carlson, 2012). This study is aimed to contribute to the literature to examine the website service innovativeness. Following this, perceived overall service quality, customer loyalty, and perceived customer value are factors that are frequently examined in marketing literature. However, no empirical study to date has investigated these constructs in a single framework including the website service innovativeness. The purpose of this study is to measure the relationships between the website service innovativeness and perceived overall service quality, customer loyalty, and perceived customer value. The present study examined the website innovativeness in the context of shaping consumer behavior. Moreover, this study seeks to contribute to the internet marketing literature by examining the impact of website service innovativeness on perceived overall service quality, customer loyalty, and perceived customer value.

\section{Service Innovativeness}

The prevalent advantage of market-creating innovations includes saving customers' time and effort. For example, in product categories, regard and examine the microwave oven, the videocassette recorder and the cellular telephone; for services, the bank ATM, the online bookstore and the Internet search engine (Berry et al., 2006). Innovation is more of a strategic obligation than an option especially for service firms (Zolfagharian \& Paswan, 2009). Service innovations differ from goods innovations in important ways and they are less tangible and testable. Therefore, perceived risks are more difficult to protect with patents; in addition, they are more difficult for firms to scale and store and hard for customers to return (Dotzel, Shankar, \& Berrt, 2013).

The innovation procedure has been stated for fundamental, incremental, truly new, disconnected, and fake innovations, as well as for architectural, modular, improving, and historical innovations (Garcia \& Calantone, 2002). Customers confront increased risk with innovations because they have to evaluate an unfamiliar core benefit and cannot control or observe when or how the benefit is produced (Berry et al., 2006). E-innovations are new services that provide customer benefits primarily through the Internet (Dotzel et al., 2013).

Innovativeness is domain specific; that is, consumers tend to be innovators for specific product categories. It is thought that innovators are not only opinion leaders, they are also well informed about the new products, more involved in product classification, are more open to media, and tend to be more important users of the product category (Goldsmith \& Newell, 1997). Garcia \& Calantone (2002) describe innovativeness as "a measure of the possible interruption that a product (process or service) can create in marketing and technological processes". From a macro viewpoint, "innovativeness" is a new idea capacity to form a 
paradigm shift in science, technology or market structure in an industry. From a micro viewpoint, "innovativeness" is a new innovation capacity to impact the company's existing marketing resources, technological resources, skills, knowledge or strategy.

Garcia \& Calantone (2002) separate product innovation from product innovativeness, indicating that product innovation shows a connection with the process through which an invention stands as a marketable product, whereas product innovativeness refers to the degree to which innovated, marketable products are new to the market. Service innovativeness has a positive effect on innovation success (Carmano-Lavoda et al., 2013). Garcia \& Calantone (2002) emphasize that a research on innovativeness can be carried out from one of its three levels, namely world, industry-market or firm.

Service innovativeness is a concept that captures service innovation at a macro level with regards to the market, which is more suitable to explain innovation performance (CarmanoLavoda et al., 2013). Service innovativeness noticeably affect customers' behaviours as well as behaviours of competing companies (Berry et al., 2006). Furthermore, service innovativeness has been seen as a major success factor in being able to differentiate a new service from its competing offerings (Cheng, Shiu, \& Dawson, 2014). O'Cass \& Carlson (2012) conceptualized website-service innovativeness in their study. Consumer perceptions of website-service innovativeness are not only relevant to aspects of uniqueness with its features, functionality, and usefulness (i.e., service processes), they are also reflections of the retailers brand and its meaning to consumers. The exogenous variable is the website service innovativeness in this study. It is also possible to describe it as the main variable. The impact of website service innovativeness on customers' behaviors has been investigated from customer perspective.

\section{Perceived Overall Service Quality}

Perceived quality can be defined as the consumers' judgment about a products' overall excellence or superiority (Zeithaml, 1988). According to Parasuraman, Zeithaml, and Malhotra (2005), perceived service quality is defined as the experience gained from the interactions between companies and customers. According to Zeithaml, Parasuraman, and Malhotra (2002), services continue both during the purchase and after the sale.

The basis of service quality is the need to the maintenance of service objectives in connection with customer expectations (Hernon \& Nitecki, 2001). In this respect, quality perception of customers is the critical determinant of shopping behavior and product choice (Zeithaml, 1988). If the perceived service quality is favorable to the user, overall satisfaction of the users, the willingness to suggest the system to others, and the tendency to buy or repurchase will trigger (Zeithaml, 2000). Likewise, the high quality of service as perceived by customers often leads to favorable behavioral intentions while low quality of service cause negative behavioral intentions (Udo, Bagchi, \& Kirs, 2010). Indeed, the perceived service quality directly effects the buying and selling tendencies of the customers (Boulding, Kalra, Staelin, \& Zeithaml, 1993).

Website facilitates efficient and effective shopping, purchasing, and delivery of goods and services (Zeithaml et al. 2002). If customers can not access the requested information from website, can not perform the requested transactions, can not deliver product or service on time 
or feel lack of communication between parties, they reduce the perceived quality of the website (Parasuraman et al., 2005). In this study, perceived overall service quality is considered as one of the endogenous variables.

\section{Customer Loyalty}

Dick \& Basu (1994) stated that customer loyalty can be viewed as the relationship between an individual's relative attitude and repeat patronage. Besides, companies need to maintain customer loyalty in order to survive (Reichheld \& Schefter, 2000). In other words, ensuring customer loyalty is significantly a factor toward long-term survival (Dick \& Basu, 1994) and it affects the existence and development of the companies (Fornell, 1992).

Due to the importance of loyalty in the electronic commerce, there is a growing interest in the business forums and in the academic community (Casalo', Flavián, \& Guinalíu, 2008). According to Anderson \& Srinivasan (2003), e-loyalty is described as the positive attitude of the customer towards an electronic business and thus, re-buying behavior is achieved. For Cyr (2008), e-loyalty intends to consider purchasing from a website in the future and with the intention of visiting or using a website in the future.

Toufaily, Ricard and Perrien (2013) argue that the concept of online loyalty expands the traditional loyalty notion to the consumer's online behavior. Customer loyalty is one of the most important basis assets of a company. The company develops a mutual benefit relationship with its customers by creating and maintaining customer loyalty (Pan, Sheng, \& Xie, 2012). In the consumer marketing community, customer loyalty has long been considered as a notable object (Reichheld \& Schefter, 2000). Likewise, customer loyalty is considered as one of the endogenous variables in this study.

\section{Perceived Customer Value}

Zeithaml (1988) defined that perceived value generally assesses consumers' use of a product based on the perception of what is received and what is given. In marketing, value is often defined from the perspective of the consumer. Similarly, the most common definition of value in the marketing literature is as a ratio of total benefits, received to total sacrifices (Patterson, Johnson, \& Spreng, 1997). In other words, Sirdeshmukh, Simgh and Sabol (2002) explain value as the customer's understanding of the benefits substracting the value of preserving an ongoing relationship with a service provider.

According to Woodruff (1997), customer value refers to assessing the customer's perceived preference and ranking the product characteristics, feature performances, and the consequences of the outcomes that lead to the attainment of customer goals. Huang \& Zhang (2008) define customer value as the functionality and replaceability of a particular product brand.

A customer will choose the competing product that offers the best value, meaning the best combination of benefits and price (Keeney, 1999). In this respect, perceived value is important in shaping the behavior of the customers. Perceived customer value is considered as one of the endogenous variables in this study. 


\section{The Study}

This paper focuses on the website service innovativeness, perceived overall site quality, customer loyalty, and perceived customer value. Moreover, the current study is a review of the structural model to test the hypotheses. Figure 1 summarizes the proposed model and the hypotheses that have been formulated.

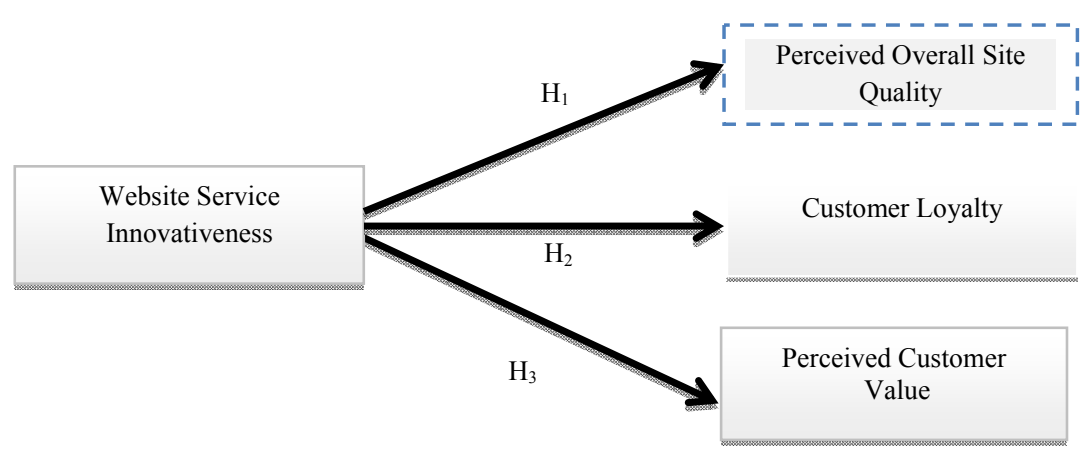

Figure 1. Proposed research model

\section{Research Hypotheses}

Service quality deals with the interaction between customers and service providers (Hernon \& Nitecki, 2001). According to Agrawal, Shah, and Wadhwa (2007), the impact of the web site quality in the formation of the perceived overall service quality is very important in the trade made in the electronic media. Goldsmith (2002) expressed the results that global innovativeness, involvement with the Internet, and Internet innovativeness all play a role in explaining online shopping and shopping intentions. In this respect, O'Cass and Carlson (2012) stated that website service innovativeness is positively related to perceived overall site quality. Thus, the following hypothesis is proposed in the current study:

$\mathbf{H}_{1}$ : Website service innovativeness has a direct and positive influence on perceived overall site quality.

Customer loyalty is one major driver of success in e-commerce (Reichheld \& Schefter, 2000). Following this, the growth and advent of Business to Consumer (B2C) e-commerce has increased the importance of creating a loyal visitor base to an e-commerce website (Gommans, Krishnan, \& Scheffold, 2001). Goldsmith (2002) has found similar relationships between innovativeness and online customer behaviour. The positive perception of the innovation of the website service in the interaction process between the consumer and the retailer's website affects the re-viewing of the website, reduced probability of switching behavior, and the intention to buy (O'Cass \& Carlson, 2012). These are tackled the context of loyalty in the marketing literature. Garcia \& Calantone's (2002) define innovativeness as the tendency to develop new products. According to Berry et al. (2006), innovation creates customer loyalty. Specifally, O'Cass \& Carlson (2012) supported that website-service innovativeness is positively related to website loyalty. Thus, the following hypothesis is proposed in the current study: 
$\mathbf{H}_{2}$ : Website service innovativeness has a direct and positive influence on customer loyalty. In recent years, providing impressive online experiences through websites has been a major issue in improving the response and results of positive consumer behaviour in the internet environment (O'Cass \& Carlson, 2010). Customer value is considered fundamental for all marketing activities (Yang \& Peterson, 2004); but, little research has addressed customer value construct. There hasn't been found study about impact of website service innovativeness on perceived customer value in the literature. However, it is thought that this effect exists. Thus, the following hypothesis is proposed in current study:

$\mathbf{H}_{3}$ : Website service innovativeness has a direct and positive influence on perceived customer value.

These hypotheses focus on the interrelationships between website service innovativeness and perceived overall site quality, customer loyalty, and perceived customer value. Since there is no study in the marketing literature in this direction, this study was intended to be done.

\section{Method}

This study was conducted in Turkey and face to face survey method was used to collect the data which was gathered from 450 undergraduate students. They were selected via a convenience sampling method. Student consumers are an appropriate sample for study because of being the young consumers who are predominantly engaged in online purchasing and also discovering market opportunities. The questionnaire consists of two parts. The first section of the questionnaire contained demographic questions asking respondents to report their sex. In the second section, there were statements about the factors to be measured. This section measured the respondent's perception of each construct in the proposed model within the study.

The questionnaire used in this study was designed according to related literatures. The variables in the study were measured using established scales from literature and these were adapted to the context of the study. Initially, website service innovativeness was measured by O'Cass and Carlson (2012) which included three items. Perceived overall site quality was measured by four items scale adapted from Yoo \& Donthu (2001). Customer loyalty was measured by O'Cass and Carlson (2012) which included three items. Lastly, perceived customer value was measured using three items adapted from Kim \& Niehm (2009). All items were measured on five-point Likert-type scales indicating (5) strongly disagree to (1) strongly agree.

In order to test the proposed model, firstly, Explanatory Factor Analysis (EFA) was conducted to investigate factor structures of the items, and the Kaiser-Meyer-Olkin (KMO) sample sufficiency and the Bartlett's Test of Sphericity was performed. Then, the reliability of each factor was estimated by computing its Cronbach's Alpha Coefficient. After EFA, Confirmatory Factor Analysis (CFA) was performed. Moreover, convergent validity, discriminant validity for construct validity, and composite reliability were calculated. Subsequently, hypotheses were tested by structural equation modeling within the research model proposed in the study. AMOS was used to create the covariance-based structural equation model (SEM). IBM SPSS 21.0 and AMOS 21.0 statistical package programs were used in the analyzes. 


\section{Results}

According to the gender analysis, $49.6 \%$ of the participants were female and $54.4 \%$ were male. Then, factor loadings of each item were determined within the factor analysis. Following this, the KMO test that measures the sample adequacy, the Bartlett's Test of Sphericity that measures the adequacy of the correlations in the correlation matrix, varimax rotation, and the variance ratios explained by each factor were analyzed. For EFA, eigenvalue greater than 1 was used (Kaiser, 1958). As shown in Table 1, eigenvalues above 1.0 were acquired in the analyses. Hair, Black, Babin, and Anderson (1998) claim that factor loadings of 0.50 or greater than that are considered practically significant. According to this rule, two observed variables, POSQ4 and CL1, were eliminated. Enough factors to meet a specified percentage of variance explained to be usually $60 \%$ or higher (Hair et al., 1998). As it is shown in Table 1, variances explained were found to be higher than $60 \%$ and they varied between 0.73 and 0.84 . According to Hair et al. (1998), the data are valid if the value of KMO is 0.5 or greater. As presented in Table 1, since the value of KMO of the data in current study is between 0.500 and 0.683 , it confirms that factor analysis is appropriate. As KMO, the Bartlett's Test of Sphericity was significant.

The Cronbach's Alpha indicator was used to assess the reliability of the scales considering a minimum value of 0.7 (Nunnally, 1978). All of the scales are extreme reliable (Cronbach's Alpha for website service innovativeness scale: 0.81; Cronbach's Alpha for overall site Quality scale: 0.80; Cronbach's Alpha for Customer loyalty scale: 0.81; and Cronbach's Alpha for perceived customer value scale: 0.82 ). All methods indicated further factor analysis as appropriate. The results that obtained from all these analyzes are significant. All these results are presented in Table 1.

Table 1

\begin{tabular}{|c|c|c|c|c|c|c|}
\hline Latent Variables & Observed Variables & Factor Loading & KMO & Eigenvalue & $\begin{array}{c}\text { Variance } \\
\text { Explained (\%) }\end{array}$ & $\begin{array}{c}\text { Cronbach's } \\
\text { Alpha }\end{array}$ \\
\hline \multirow{3}{*}{ Website Service Innovativeness (WSI) } & WSI1 & 0.77 & \multirow{3}{*}{0.65} & \multirow{3}{*}{2.20} & \multirow{3}{*}{73.47} & \multirow{3}{*}{0.81} \\
\hline & WSI2 & 0.91 & & & & \\
\hline & WSI3 & 0.97 & & & & \\
\hline \multirow{4}{*}{ Perceived Overall Site Quality (POSQ) } & POSQ1 & 0.89 & \multirow{4}{*}{0.66} & \multirow{4}{*}{2.24} & \multirow{4}{*}{74.90} & \multirow{4}{*}{0.80} \\
\hline & POSQ2 & 0.91 & & & & \\
\hline & POSQ3 & 0.77 & & & & \\
\hline & POSQ4* & - & & & & \\
\hline \multirow{3}{*}{ Customer Loyalty (CL) } & CL1* & - & \multirow{3}{*}{0.50} & \multirow{3}{*}{1.69} & \multirow{3}{*}{84.66} & \multirow{3}{*}{0.81} \\
\hline & CL2 & 0.92 & & & & \\
\hline & CL3 & 0.92 & & & & \\
\hline \multirow{3}{*}{ Perceived Customer Value (PCV) } & PCV1 & 0.82 & \multirow{3}{*}{0.68} & \multirow{3}{*}{2.21} & \multirow{3}{*}{73.92} & \multirow{3}{*}{0.82} \\
\hline & PCV2 & 0.90 & & & & \\
\hline & PCV3 & 0.84 & & & & \\
\hline
\end{tabular}

*Eliminated observed variables

Table 2 exhibits the correlation matrix for variables, Average Variance Extracted (AVE), and Composite Reliabilities (CR)Values. 
Table 2

Correlation Matrix for Variables, Average Variance Extracted (AVE), and Composite Reliabilities (CR)Values

\begin{tabular}{lcccc}
\hline Construct & $\begin{array}{c}\text { Website Service } \\
\text { Innovativeness (WSI) }\end{array}$ & $\begin{array}{c}\text { Perceived Overall } \\
\text { Site Quality (POSQ) }\end{array}$ & $\begin{array}{c}\text { Customer Loyalty } \\
\text { (CL) }\end{array}$ & $\begin{array}{c}\text { Perceived Customer } \\
\text { Value (PCV) }\end{array}$ \\
\hline Website Service Innovativeness (WSI) & $\begin{array}{c}0.89) \\
\mathbf{0 . 7 3}\end{array}$ & & & \\
Perceived Overall Site Quality (POSQ) & $0.56^{*}$ & $(0.89)$ & $\mathbf{0 . 7 4}$ & $(0.91)$ \\
& $0.49^{*}$ & $0.40^{*}$ & $\mathbf{0 . 8 4}$ & $(0.89)$ \\
Customer Loyalty (CL) & $0.60^{*}$ & $0.60^{*}$ & $0.51^{*}$ & $\mathbf{0 . 7 3}$ \\
Perceived Customer Value (PCV) & & & \\
\hline
\end{tabular}

*Correlations were showed between the constructs on the diagonal and correlation was significant at the 0.01 level (two-tailed).

** The bold scores showed the average variance extracted (AVE) of the individual constructs on the diagonal.

*** Composite reliabilities (CR) were showed in bracket on the diagonal.

Jöreskog (1971) claimed the need to use composite reliability (CR). Composite reliability should be 0.7 or higher to indicate adequate converge or internal consistency (Hair et al., 1998). As shown in Table 2, the composite reliabilities of all constructs were from 0.89 to 0.91 in this study. The results indicated composite reliability of all measures. Construct validity is assessed considering two types of standard including convergent validity and discriminatory validity. For convergent validity, the AVE-scores surpassed the recommended level of 0.50 (Hair et al., 1998). For discriminant validity, square root of each variable's AVE value is greater than the correlation of each dimension with other dimensions (Fornell \& Larcker, 1981). The results indicated convergent validity and discriminant validity of all measures. In short, the results were satisfactory. After exploratory factor analysis (EFA), in the next step, confirmatory factor analysis (CFA) was conducted on the measurement model using AMOS software. AMOS software provides a number of model goodness fit indices. The results of the Confirmatory Factor Analysis (CFA) are given in Table 3.

Table 3

Confirmatory Factor Analysis (CFA) Results

\begin{tabular}{|c|c|c|c|c|c|}
\hline Latent Variables & Observed Variables & $\begin{array}{c}\text { Standardized Regression } \\
\text { Weights }\end{array}$ & Standard Error & T-Value & $\mathrm{p}$ \\
\hline \multirow{3}{*}{ Website Service Innovativeness (WSI) } & WSI1 & 0.63 & & & \\
\hline & WSI2 & 0.66 & 0.077 & 13.138 & $* * *$ \\
\hline & WSI3 & 0.63 & 0.090 & 11.221 & $* * *$ \\
\hline \multirow{4}{*}{ Perceived Overall Site Quality (OSQ) } & POSQ1 & 0.86 & & & \\
\hline & POSQ2 & 090 & 0.048 & 22.196 & $* * *$ \\
\hline & POSQ3 & 0.60 & 0.052 & 13.609 & $* * *$ \\
\hline & POSQ4* & - & & & \\
\hline \multirow{3}{*}{ Customer Loyalty (CL) } & CL1* & - & & & \\
\hline & CL2 & 0.81 & & & \\
\hline & CL3 & 0.83 & 0.056 & 17.408 & $* * *$ \\
\hline \multirow{3}{*}{ Perceived Customer Value (PCV) } & PCV1 & 0.72 & & & \\
\hline & PCV2 & 0.88 & 0.063 & 16.931 & $* * *$ \\
\hline & $\mathrm{PCV} 3$ & 0.74 & 0.064 & 14.818 & $* * *$ \\
\hline
\end{tabular}

\footnotetext{
* Eliminated observed variables

**Fit Indices: $x^{2}$ /df: 2.635; RMSEA:0.060; NFI:0.968; CFI:0.980; SRMR:0.027; AGFI: 0.931; GFI: 0.964

$* * * p<0.01$
}

Results showed that the standardized regression coefficients for the observed variables, $t$ values $(t>1.96)$, and $p$ values $(p<0.01)$ were significant. 
Table 4 shows the generally accepted goodness fit index values in the literature (Schermelleh-Engel et al., 2003) and values were obtained after analysis in this study.

Table 4

The Fit Indexes and Analysis Results for Measurement Model

\begin{tabular}{lccc}
\hline Fit Index & Good Fit Indexes & Acceptable Fit Indexes & Values Obtained \\
\hline $\mathrm{x}^{2} / \mathrm{df}$ & $0 \leq \chi^{2} / \mathrm{df} \leq 2$ & $2<\chi^{2} / \mathrm{df} \leq 3$ & 2.635 \\
$\mathrm{RMSEA}$ & $0 \leq \mathrm{RMSEA} \leq 0.05$ & $0.05<\mathrm{RMSEA} \leq 0.08$ & 0.060 \\
$\mathrm{NFI}$ & $0.95 \leq \mathrm{NFI} \leq 1.00$ & $0.90 \leq \mathrm{NFI}<0.95$ & 0.968 \\
$\mathrm{CFI}$ & $0.97 \leq \mathrm{CFI} \leq 1.00$ & $0.95 \leq \mathrm{CFI}<0.97$ & 0.980 \\
$\mathrm{SRMR}$ & $0 \leq \mathrm{SRMR} \leq 0.05$ & $0.05<\mathrm{SRMR} \leq 0.10$ & 0.027 \\
$\mathrm{AGFI}$ & $0.90 \leq \mathrm{AGFI} \leq 1.00$ & $0.85 \leq \mathrm{AGFI}<0.90$ & 0.931 \\
GFI & $0.95 \leq \mathrm{GFI} \leq 1.00$ & $0.90 \leq \mathrm{GFI}<0.95$ & 0.964 \\
\hline$x^{2}$
\end{tabular}

$\boldsymbol{x}^{2}$ : Chi-Square; df:Degree of Freedom; RMSEA: Root Mean Square Error of Approximation; SRMR: Standardized Root Mean Square Residual NFI: Normed Fit Indeksi; CFI: Comparative Fit Index; AGFI: Adjusment Goodness of Fit Index; GFI: Goodness Of Fit Index.

These results revealed that only $x^{2} / s d$ and RMSEA have acceptable level fit indexesand all the others excess good fit indexes; that is, the proposed measurement model demonstrated good measurement properties. On the basis of these collective findings, it is possible to express the acceptability of the structural model.

In addition, the path diagram of the research model is presented in Figure 2.

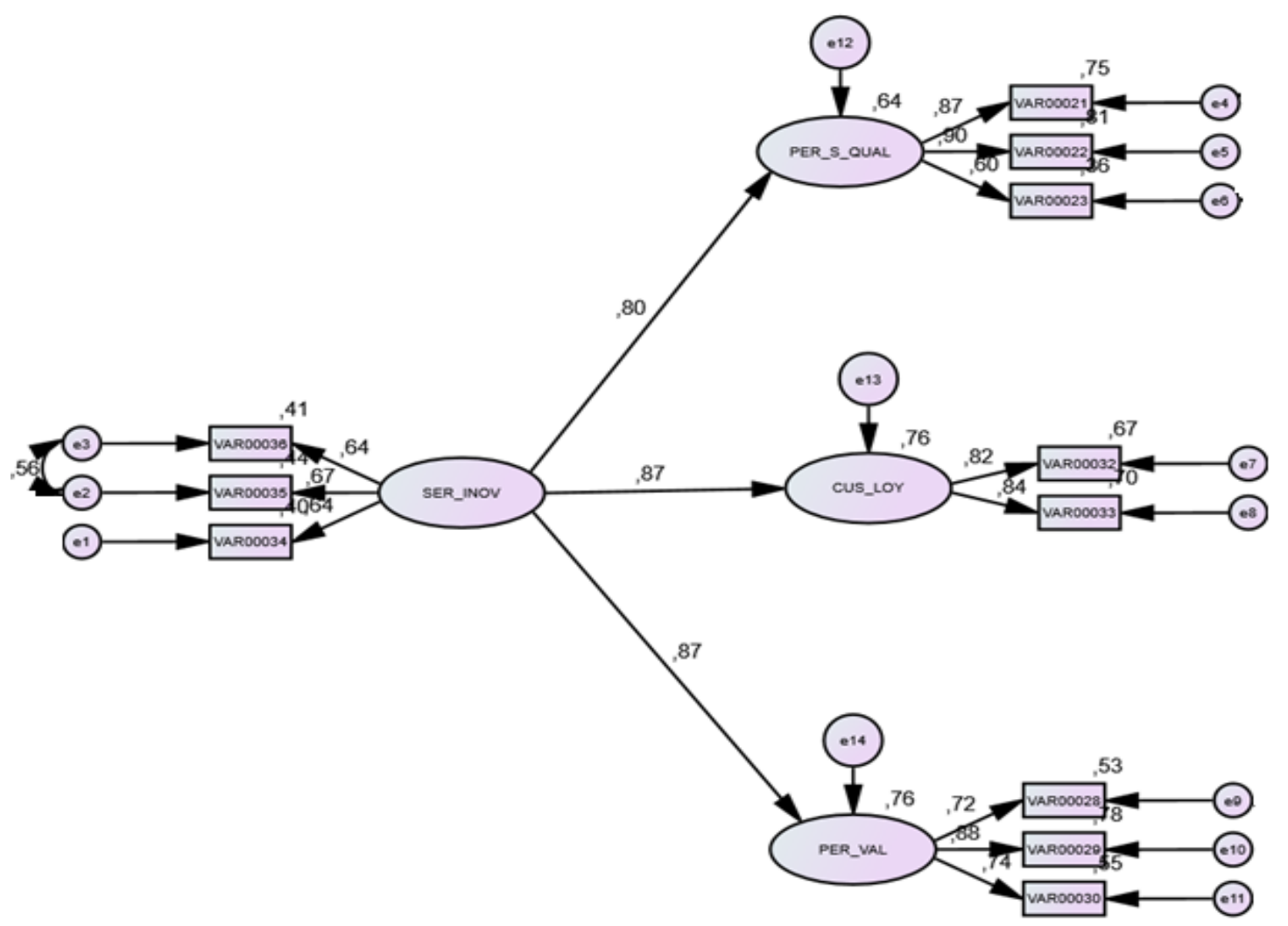

Figure 2. The path analysis of the proposed model

*Fit Indices: $x^{2}$ /sd: 2.635; RMSEA:0.060; NFI:0.968; CFI:0.980; SRMR:0.027; AGFI: 0.931; GFI: 0.964. 
The results of the path analysis indicated that website service innovativeness had significant and positive impact on perceived overall site quality, customer loyalty, and perceived customer value. Table 5 indicates the standardized path coefficients, coefficients of determination $\left(\mathrm{R}^{2}\right)$ of the latent variables, and hypothesis results.

Table 5

Structural Model

\begin{tabular}{clccc}
\hline & Path & $\begin{array}{c}\text { Standardized } \\
\text { Coefficients }\end{array}$ & $\begin{array}{c}\text { Hypothesis } \\
\text { Results }\end{array}$ & $\mathrm{R}^{2}$ \\
\hline $\mathrm{H}_{1}$ & Website Service Innovativeness (WSI)<--- Overall Site Quality (POSQ) & 0.803 & Supported & 0.64 \\
$\mathrm{H}_{2}$ & Website Service Innovativeness (WSI)<--- Customer Loyalty (CL) & 0.872 & Supported & 0.76 \\
$\mathrm{H}_{3}$ & Website Service Innovativeness (WSI)<--- Perceived Customer Value (PCV) & 0.871 & Supported & 0.75 \\
\hline$* \mathrm{p}<0.01 * * \mathrm{t}>1.96$ & & &
\end{tabular}

All of the hypotheses were supported at the 0.01 level. As a result, there were found a positive and significant effect of website service innovativeness on perceived overall site quality $(\beta=0.80)$, customer loyalty $(\beta=0.87)$, and perceived customer value $(\beta=0.87)$. The results indicated that perceived overall site quality $\left(R^{2}=0.64\right)$; customer loyalty $\left(R^{2}=0.76\right)$, and perceived customer value $\left(\mathrm{R}^{2}=0.75\right)$ could be clearly explained by website service innovativeness. To sum up, based on the above results, $\mathrm{H}_{1}, \mathrm{H}_{2}$, and $\mathrm{H}_{3}$ were confirmed. Thus, taking all these results into account, it is possible to say that website service innovativeness had significant and positive impact on perceived overall site quality, customer loyalty, and perceived customer value.

\section{Discussion and Conclusion}

Services have became increasingly important in economic development. Over the last few years, increasing attention has been given by both researchers and practitioners to how organizations can become innovative. Therefore, innovativeness is an important dimension in the service sector. The current paper contributes to the literature of service innovativeness. The paper adds to the literature by investigating the relationship between service innovativeness and perceived overall service quality, customer loyalty, and perceived customer value from the consumer's viewpoint. The need for conducting the study has been considered due to the lack of empirical studies that analyze service innovativeness, perceived overall service quality, customer loyalty, perceived customer value development in the ecommerce context, and the increasing competitiveness in electronic business. This research provides a holistic and comprehensive approach by measuring the relationship between service innovativeness and perceived overall service quality, customer loyalty, and perceived customer value. Moreover, the current research contributes primarily to the theoretical viewpoints about service innovativeness, perceived overall service quality, customer loyalty, and perceived customer value.

The structural model was empirically tested. The use of structural equation modeling in this investigation suggests a linear relationship between the variables in proposed model. Path analysis exhibited that model fit the data well. Thus, the results showed that $\mathrm{H}_{1}, \mathrm{H}_{2}$, and $\mathrm{H}_{3}$ are supported. The proposed model was strongly supported by the data collected in Turkey. 
The results indicated that service innovativeness content have a significant and positive influence on customers overall service quality, customer loyalty, and value. To sum up, the findings presented that website service innovativeness is an important driver of behavioral intentions. Service innovativeness play a crucial role on perceived overall service quality, customer loyalty, and perceived customer value. To this end, the more managers place importance to website service innovativeness, the more perceived overall service quality, customer loyalty, and perceived customer value will increase. According to the results of this study regarding the context of shopping site, website innovativeness is very important on the formation of customer perceptions. Considering the results, both statistical evidence and theoretical evidence show that innovativeness is notable for sensations of customer in shopping site.

The findings will benefit both practitioners and researchers in developing an understanding of the factors. The findings of this study have several implications for researchers and marketing managers. Some limitations should be addressed: The main limitation of this study is sample and therefore, it may not be generalizable to other populations. In addition, it is possible to enrich the research model by including factors that are effective in service innovativeness.

\section{References}

Agarwal, S., Krishna Erramilli, M., \& Dev, C. S. (2003). Market orientation and performance in service firms: role of innovation. Journal of Services Marketing, 17(1), 68-82.

Agrawal, A., Shah, P., \& Wadhwa, V. (2008). EGOSQ-users' assessment of e-governance online-services: A quality measurement instrumentation. In International Conference on E-governance, Hydrabad, India, 231-244.

Anderson, R. E., \& Srinivasan, S. S. (2003). E-satisfaction and e-loyalty: A contingency framework. Psychology \& Marketing, 20(2), 123-138.

Berry, L. L., Shankar, V., Parish, J. T., Cadwallader, S., \& Dotzel, T. (2006). Creating new markets through service innovation. MIT Sloan Management Review, 47(2), 56-63.

Boulding, W., Kalra, A., Staelin, R., \& Zeithaml, V. A. (1993). A dynamic process model of service quality: from expectations to behavioral intentions. Journal of Marketing Research, 30(1), 7-27.

Carmona-Lavado, A., Cuevas-Rodríguez, G., \& Cabello-Medina, C. (2013). Service innovativeness and innovation success in technology-based knowledge-intensive business services: An intellectual capital approach. Industry and Innovation, 20(2), 133-156.

Casaló, L., Flavián, C., \& Guinalíu, M. (2008). The role of perceived usability, reputation, satisfaction and consumer familiarity on the website loyalty formation process. Computers in Human Behavior, 24(2), 325-345.

Cheng, C. C., Shiu, E. C., \& Dawson, J. A. (2014). Service business model and service innovativeness. International Journal of Innovation Management, 18(2), 1-27.

Cyr, D. (2008). Modeling web site design across cultures: relationships to trust, satisfaction, and e-loyalty. Journal of Management Information Systems, 24(4), 47-72.

Dick, A. S., \& Basu, K. (1994). Customer loyalty: toward an integrated conceptual framework. Journal of the Academy of Marketing Science, 22(2), 99-113.

Dotzel, T., Shankar, V., \& Berry, L. L. (2013). Service innovativeness and firm value. Journal of Marketing Research, 50(2), 259-276.

Fornell, C. (1992). A national customer satisfaction barometer: The Swedish experience. Journal of Marketing, 56(1), 6-21.

Fornell, C., \& Larcker, D. F. (1981). Evaluating structural equation models with unobservable variables and measurement error. Journal of Marketing Research, 18(1), 39-50.

Garcia, R., \& Calantone, R. (2002). A critical look at technological innovation typology and innovativeness terminology: A literature review. Journal of Product Innovation Management, 19(2), 110-132. 
Goldsmith, R. E. (2002). Explaining and predicting consumer intention to purchase over the internet: An exploratory study. Journal of Marketing Theory and Practice, 10(2), 22-28.

Goldsmith, R. E., \& Newell, S. J. (1997). Innovativeness and price sensitivity: managerial, theoretical and methodological issues. Journal of Product \& Brand Management, 6(3), 163-174.

Gommans, M., Krishnan, K.S., \& Scheffold, K.B. (2001). From brand loyalty to e-loyalty: A conceptual framework. Journal of Economic and Social Research, 3(1), 43-58.

Hair, J. F., Black, W. C., Babin, B. J., \& Anderson, R. E., (1998). Multivariate data analysis (5 ${ }^{\text {th }}$ ed.). Upper Saddle River, NJ. Prentice-Hall.

Hernon, P., \& Nitecki, D. A. (2001). Service quality: A concept not fully explored. Library Trends, 49(4), 687-708.

Huang, J., \& Zhang, D. (2008, November). Customer value and brand loyalty:Multi-dimensional empirical test. Future Information Technology and Management Engineering, FITME'08, International Seminar on IEEE, United Kingdom.

Jöreskog, K. G. (1971). Statistical analysis of sets of congeneric tests. Psychometrika, 36, 109-133.

Kaiser, H. F. (1958). The varimax criterion for analytic rotation in factor analysis. Psychometrika, 23(2), 187-200.

Keeney, R. L. (1999). The Value of Internet Commerce to the Customer. Management Science, 45(4), 533-542.

Kim, H., \& Niehm, L. S. (2009). The impact of website quality on information quality, value and loyalty intentions in apparel retailing. Journal of Interactive Marketing, 23(3), 221-233.

Lee, R. P., Ginn, G. O., \& Naylor, G. (2009). The impact of network and environmental factors on service innovativeness. Journal of Services Marketing, 23(6), 397-406.

Liu, S. (2013). The role of service innovativeness in the relationship between market orientation and innovative performance: moderator or mediator?. The Service Industries Journal, 33(1), 51-71.

McDonald, M. H., De Chernatony, L., \& Harris, F. (2001). Corporate marketing and service brands-Moving beyond the fastmoving consumer goods model. European Journal of Marketing, 35(3-4), 335-352.

Nunnally, J. C. (1978). Psychometric theory (2 ${ }^{\text {nd }}$ ed.). New York: McGraw-Hill.

O'Cass, A., \& Carlson, J. (2010). Examining the effects of website-induced flow in professional sporting team websites. Internet Research, 20(2), 115-134.

O'Cass, A., \& Carlson, J. (2012). An e-retailing assessment of perceived website-service innovativeness: Implications for website quality evaluations, trust, loyalty and word of mouth. Australasian Marketing Journal (AMJ), 20(1), 28-36.

Pan, Y., Sheng, S., \& Xie, F. T. (2012). Antecedents of customer loyalty: An empirical synthesis and reexamination. Journal of Retailing and Consumer Services, 19(1): 150-158.

Parasuraman, A., Zeithaml, V. A., \& Malhotra, A. (2005). ES-QUAL a multiple-item scale for assessing electronic service quality. Journal of Service Research, 7(3), 213-233.

Patterson, P. G., Johnson, L. W., \& Spreng, R. A. (1997). Modeling the determinants of customer satisfaction for business-tobusiness professional services. Journal of the Academy of Marketing Science, 25(1), 4-17.

Ranganathan, C., \& Ganapathy, S. (2002). Key dimensions of business-to-consumer web sites. Information \& Management, $39(6), 457-465$.

Reichheld, F. F., \& Schefter, P. (2000). E-loyalty. Harvard Business Review, 78(4), 105-113.

Schermelleh-Engel, Karin, Helfried Moosbrugger \& Hans Müller (2003). Evaluating the fit of structural equation models: tests of significance and descriptive goodness-of-fit measures. Methods of Psychological Research Online, 8(2), 23-74.

Sirdeshmukh, D., Singh, J., \& Sabol, B. (2002). Consumer trust, value, and loyalty in relational exchanges. Journal of Marketing, 66(1), 15-37.

Toufaily, E., Ricard, L, \& Perrien, J. (2013). Customer loyalty to a commercial website: descriptive meta-analysis of the empirical literature and proposal of an integrative model. Journal of Business Research, 66: 1436-1447.

Udo, G.J., Bagchi, K.K., \& Kirs, P.J. (2010). An assessment of customers' e-service quality perception, satisfaction and intention. International Journal of Information Management, 30(6), 481-492.

Woodruff, R. B. (1997). Customer value: The next source for competitive advantage. Journal of the Academy of Marketing Science, 25(2), 139-153.

Yang, Z., \& Peterson, R. T. (2004). Customer perceived value, satisfaction, and loyalty: The role of switching costs. Psychology \& Marketing, 21(10), 799-822.

Yoo, B., \& Donthu, N. (2001). Developing a scale to measure the perceived quality of an Internet shopping site (SITEQUAL). Quarterly Journal of Electronic Commerce, 2(1), 31-45. 
Zeithaml, V. A. (1988). Consumer perceptions of price, quality, and value: A means-end model and synthesis of evidence. Journal of Marketing, 52(3), 2-22.

Zeithaml, V. A. (2000). Service quality, profitability, and the economic worth of customers: what we know and what we need to learn. Journal of the Academy of Marketing Science, 28(1), 67-85.

Zeithaml, V. A., Parasuraman, A., \& Malhotra, A. (2002). Service quality delivery through web sites: A critical review of extant knowledge. Journal of the Academy of Marketing Science, 30(4), 362-375.

Zolfagharian, M. A., \& Paswan, A. (2009). Perceived service innovativeness, consumer trait innovativeness and patronage intention. Journal of Retailing and Consumer Services, 16(2), 155-162. 